\title{
Why do candidates use online media in constituency campaigning? An application of the theory of planned behavior
}

\author{
Marcinkowski, Frank ; Metag, Julia
}

\begin{abstract}
Campaigners are increasingly citing the Web as an important election tool for candidates and parties to communicate with voters; however, to what extent is this rhetoric matched to reality? Evidence suggests there is something of a gap in the importance attributed to the medium and the extent to which it is actually adopted. Most studies of the drivers of Web campaigning to date have focused on the environmental factors and personal resources that determine individuals' use of the medium. We argue here that such models miss a key layer of explanation in accounting for web uptake by politicians-that of individual attitudes and subjective assessments of the value of the Internet as a campaign tool. More specifically, by applying the Theory of Planned Behavior, we account for patterns of Web campaign activity among candidates in a German state level election. We test our model on survey data and an independent audit of Web use by candidates. Our findings confirm that there is a large discrepancy between the intention to use Web campaigning and actual adoption. Furthermore, the theory is confirmed as a useful explanatory of the Web campaigning that does occur, although the individual components of the theory vary in importance.
\end{abstract}

DOI: https://doi.org/10.1080/19331681.2014.895690

Posted at the Zurich Open Repository and Archive, University of Zurich

ZORA URL: https://doi.org/10.5167/uzh-100166

Journal Article

Originally published at:

Marcinkowski, Frank; Metag, Julia (2014). Why do candidates use online media in constituency campaigning? An application of the theory of planned behavior. Journal of Information Technology Politics, 11(2):151-168.

DOI: https://doi.org/10.1080/19331681.2014.895690 
First Submission: 06/28/2013

Revised Submission: 10/07/2013

Accepted: 02/12/2014

RUNNING HEAD: WHY DO CANDIDATES USE ONLINE MEDIA?

Why Do Candidates Use Online Media in Constituency Campaigning?

An Application of the Theory of Planned Behavior.

\author{
Frank Marcinkowski \\ University of Muenster \\ Julia Metag \\ University of Zurich
}




\begin{abstract}
Campaigners are increasingly citing the web as an important election tool for candidates and parties to communicate with voters. However to what extent is this rhetoric matched to reality? Evidence suggests there is something of a gap in the importance attributed to the medium and the extent to which it is actually adopted. Most studies of the drivers of Web campaigning to date have focused on the environmental factors and personal resources that determine individuals' use of the medium. We argue here that such models miss a key layer of explanation in accounting for web uptake by politicians - that of individual attitudes and subjective assessments of the value of the internet as a campaign tool. More specifically, applying the Theory of Planned Behavior we account for patterns of Web campaign activity among candidates in a German state level election. We test our model on survey data and an independent audit of Web use by candidates. Our findings confirm there is a large discrepancy between the intention to use Web campaigning and actual adoption. Furthermore, the theory is confirmed as a useful explanatory of the web campaigning that does occur, although the individual factors components of the theory vary in importance.
\end{abstract}

Keywords: Online campaigning, state elections, Theory of Planned Behavior, German politics. 


\section{Introduction}

In Germany, as in many other democracies, there is a growing appreciation among politicians and parties of the importance of the Internet in election campaigns. As well as being a channel for parties and politicians to distribute their election programs it offers a new way for them to interact with potential voters and to mobilize their followers. Through Web sites and online social networks it becomes possible to bypass the traditional media and address citizens directly in a more targeted and personalized form (Russmann, 2011, pp. 1f.; Schweitzer \& Albrecht, 2011, pp. 25f.; Wolling, Schmolinsky, \& Emmer 2010, pp. 63f.). By the 2009 German federal and state elections the electoral benefits of the technology had become eminently clear to candidates given the high profile online presidential campaign of Barack Obama (Bieber, 2011; Lilleker \& Jackson, 2011; Schweitzer \& Albrecht, 2011).

German campaign managers caught this popular mood and sent strong signals that this election cycle would witness a sea change in internet use. Several prominent individuals went on record to underscore the importance of the Internet as "a backbone,"1 "a central element"2 or "the heart" 3 of their respective political campaigns. Whether these expectations were met is the subject for investigation of this paper.

A growing body of international research on Web campaigning has shown that it forms an increasingly important component of an election bid by parties and candidates (Chadwick \& Howard, 2009; Davis et al., 2009; Gibson \& Ward, 1998; Gibson, Margolis, Resnick, \& Ward, 2003; Lilleker \& Jackson, 2011; Schweitzer, 2006). However, despite the efforts spent at the national level it remains the case that there are significant discrepancies between the importance attributed to the Internet and how much individual politicians are actually using it in their campaigns (Carlson \& Strandberg, 2005; Druckman, Kifer, \& Parkin,

\footnotetext{
${ }^{1}$ Klaus Schüler, campaign manager (Conservatives) (quoted from Schneider, 2009).

${ }^{2}$ Robert Heinrich, head of public relations (The Green Party) (quoted from Biermann, 2009).

${ }^{3}$ Kajo Wasserhövel, then campaign manager (Social Democrats) (quoted from Wiegold, 2009).
} 
2007; Schweitzer \& Albrecht, 2011, p. 37). A number of factors may account for this contrast. First, traditional mass media in the form of television still dominates as a voter communication tool (Maier, Tenscher, \& Schüller, 2010; Schmitt-Beck \& Mackenrodt, 2009; Zittel, 2009a). In addition, politicians and campaign managers are likely to be nervous in adopting interactive technologies that challenge their more traditionally hierarchical and centralized communication strategies (Kunze, Bauer, \& Becker 2011; Lilleker \& Jackson, 2011; Norris \& Curtice, 2008; Zittel 2009a;). Finally using the technology to conduct conversations with voters during a high stakes campaign may not form the most efficient use of resources. Maintaining an authentic conversation with an electorate of several thousand people is costly and highly time consuming and beyond the capacity of most parties let alone individual candidates (Coleman, 2006). Certainly the anecdotal evidence from the German press reports following the federal election campaign indicated that it had fallen short of expectations with several damning stories appearing about how an Obama style online campaign had failed to fire. "No we can't" was one simple headline ${ }^{4}$ followed by "Obama help us", and overt criticism of the parties for their "Tiresome online campaign".

In this paper we examine the gap in expectations and performance among political elites in relation to Web campaigning more closely and systematically than has hitherto been the case. More specifically we look at the attitudes of candidates' toward Web campaigning in a state election in Germany in 2010 and how positively the technology was viewed. We then compare this with their intention to campaign online and their actual practice during the election itself in the form of Web sites and social network profiles. Our basic goal is to identify first whether any discrepancy exists in the value attributed to the Web and actual use of it for campaigning, and if so, then how to explain it from an individual psychological

\footnotetext{
${ }^{4}$ freitag.de (derFreitag, 2009).

${ }^{5}$ süddeutsche.de (Weißmüller, 2009).

${ }^{6}$ Zeit Online (Hippler, 2009).
} 
perspective. In doing so we hope to make a significant contribution to the literature which to date has focused largely on content analyses of party and candidate Web sites and more objective contextual drivers of adoption, that is, marginality, incumbency, party size and individual resources such as political experience and age (Russmann, 2011; Schweitzer, 2010).

\section{Drivers of Online Campaigning}

Among the studies that have examined the drivers of Web campaigning, a common approach has been to look at the impact of contextual factors within an election district such as its socio-demographic structure, that is, whether it has a high number of young people or highly educated individuals that would be likely to use the Web? The effect of political variables such as marginality and competitiveness have also been examined (Lev-On, 2011; Zittel, 2009b) as well as organizational variables such as the level of a candidates' support from the party, their staffing resources and budget (Druckman, Kifer, \& Parkin, forthcoming; Gibson \& McAllister, 2011; Sudulich \& Wall, 2009). These latter factors are associated with wider theoretical debates about a creeping 'normalization' of party competition online, whereby larger parties are seen as reinforcing their offline dominance through the Internet (Carlson \& Strandberg, 2005; Margolis \& Resnick, 2000; Williams \& Gulati, 2007; Zittel, 2009b).

Individual factors such as candidates' age and gender have also been considered as important in driving the move to Web campaigning. While some studies affirm that young and male candidates are more likely to conduct an online campaign (Åström \& Karlsson, 2011; Zittel, 2009b), others disclaim the idea that socio-demographic factors have any influence on this decision (Wolling, Schmolinsky, \& Emmer, 2010). Finally, strategic individual characteristics such as being an incumbent or having some type of prior experience in holding office have also been found to have an influence on whether a candidate adopts the 
Web (Lev-On, 2011). Other research has countered this, however, by showing that challengers are more likely to practice Web campaigning (Sudulich \& Wall, 2010). Explanations of these differences relate to higher internet literacy of younger candidates and the tendency to use the Internet as a means for a more individualized campaign by incumbents (Zittel, 2009a). On the contrary, incumbents may not see the need to use the Internet to reach more voters as they have already have an advantage of winning the election (Prior, 2006) and challengers engage in more risky campaigning techniques (Druckman, Kifer, \& Parkin, 2009).

These studies all share the basic assumption that to best explain patterns of Web campaigning one should seek to identify the environmental and personal resources that support the use of Web campaigning. We argue that despite this being a logical way to proceed, this approach misses a key level of explanation in understanding Web campaigning. Essentially such models capture the 'capacity' for Web campaigning, which although necessary for its practice is not sufficient to trigger uptake. This depends on an individuals' internal predisposition or motivation to do so. As noted above the commonly received 'wisdom' in this respect is that parties and candidates take a cautious approach to the Web (Russmann, 2011; Schweitzer \& Albrecht, 2011). Thus, while perceiving its benefits candidates and political parties may be somewhat reticent in building it into their wider campaign strategy given that it requires more monitoring and resources (Coleman, 2006). Applying more interactive forms of communication also carries a risk of exposure and embarrassment (Lilleker \& Jackson, 2011; Wolling, Schmolinsky, \& Emmer, 2010).

Thus, rather than focusing on external structural factors and internal resources that support Web campaigning it is the inclinations and motivations of candidates to use the Web that we argue are most important to consider when seeking to explain patterns of adoption or non-adoption. One recent and rare study by Wolling, Schmolinsky, \& Emmer (2010) has demonstrated the utility of this more psychological approach to the topic. Employing a variant of the rational choice theory - the so-called uses and gratifications approach - the authors 
seek to explain why German state politicians established a Web presence for campaign purposes. They concluded that although resources in the shape of time and financial resources available were important in explaining the use of the Web, the process was most easily understood from an individual cost-benefit perspective and a range of received gratifications. These gratifications could be political support or to gain voter feedback on their performance.

From Attitude to Action: Online-Campaigning as Planned Behavior In this paper we argue that accounts of online campaigning to date have not taken sufficient account of individuals' internet related attitudes and perceptions. It is clear from numerous studies discussed above that even if individuals have a positive view of the new media and resources to adopt they do not necessarily use it. To help unpack this conundrum we adopt a theoretical perspective with a growing reputation in social science research for understanding the discrepancies between attitudes and behavior - the Theory of Planned Behavior (TPB) (Ajzen, 1991). The TPB is an extension of the Theory of Reasoned Action (Ajzen \& Fishbein, 1980) which also sought to account for inconsistency in the attitudesbehavior relationship (LaPiere, 1934; Wicker, 1969). In this respect, the theory suggests that candidates' media-related dispositions should be part of analyzing their campaign-related online activities.

According to Ajzen and Fishbein, an individual's intention to perform a given behavior is the immediate antecedent of actual behavior (Ajzen \& Fishbein, 1980, p. 41). Ajzen and Fishbein define behavioral intentions as a measure of likelihood that an individual will perform a given behavior (Ajzen \& Fishbein, 1980, p. 42). Predictive validity is achieved if the given behavior is compatible with the measure of intention - that is, they have to refer to the same action, target, context and time (Fishbein \& Ajzen, 2010, p. 44).

The Theory of Planned Behavior assumes that behavioral intentions are determined by three interacting constructs. Intentions are results of personal, social and situational 
influences. The personal factor denotes an individual's attitude, which refers to "the evaluation of an object, concept, or behavior along a dimension of favor or disfavor, good or bad, like or dislike" (Ajzen \& Fishbein, 1980, p. 78). The more favorable an individual's attitude towards a behavior is, the stronger his intention to perform the behavior should be.

In its original formulation, the concept of subjective norm denominates the perceived social pressure to perform or not to perform a behavior (Ajzen, 1991; Ajzen \& Fishbein, 1980). In a more recent version of the theory, Ajzen and Fishbein distinguish between two types of normative pressure: injunctive and descriptive norms (see Cialdini, Reno, \& Kallgren, 1990; Fishbein \& Ajzen, 2010). “Injunctive norms refer to perceptions concerning what should or ought to be done with respect to performing a given behavior, whereas descriptive norms refer to perceptions that others are or are not performing the behavior in question" (Fishbein \& Ajzen, 2010, p. 131). Thus, an individual's behavioral intention is determined by his perception that people who are important to him support his performance of the given behavior.

Perceived behavioral control is the third determinant of intended behavior. It is defined as "the extent to which people believe that they are capable of performing a given behavior, that they have control over its performance" (Fishbein \& Ajzen, 2010, pp. 154f.). Perceived control takes internal and external factors into account. Internal factors refer to an individual's general disposition including skills and willpower. External factors include resources like time and money, dependence on other people or events, laws, and rules (Ajzen, 1985, p. 25ff.; Fishbein \& Ajzen, 2010, p. 58). Besides its indirect effect, perceived control can also have a direct influence on behavior if it reflects actual control or if the person who is acting does not have complete volitional control over his behavior (Ajzen, 1991, p. 184; Madden, Scholder-Ellen, \& Ajzen, 1992, p. 4).

Since its development by social psychologists the Theory of Planned Behavior has been used in an increasing number of contexts and disciplines. Recent studies in health 
communication for example have applied it to understand that individual attitudes and perceived behavioral control predict the intention for organ donation (Bae \& Kang, 2008; Bresnahan et al., 2007; Park \& Smith, 2007). The marketing literature has used it to model consumer behavior (George, 2002; Lim \& Dubinsky, 2005). In communication science the theory has mostly been applied in relation to media effects (Golan \& Banning, 2008; Zhao \& Cai, 2008) and theories of media diffusion and usage (Rossmann, 2010, pp. 36ff.). Some recent studies have used it to explain usage and adoption of new media, both in terms of general internet use (Doll et al., 2000; Ho et al., 2001) and Web 2.0 tools such as Wikis and video platforms (Liu, 2010; Park et al., 2010) as well as new online services (Becker et al., 2010; Papies \& Clement, 2007). The findings have shown that substantively the Theory of Planned Behavior is helpful in explaining the adoption and usage of new information and communication technologies. It demonstrates that factors such as issue involvement and perceived social pressure from the community to use the Internet predict different types of the adoption of new technologies, for example internet use by Muslims (Ho et al., 2001) or the upload of user generated content to online video platforms (Park et al., 2010).

\section{Hypotheses and Research Question}

Our research seeks to build on this existing work theoretically and empirically by applying the TPB to a new context - state level election campaigns. Use of the theory within political science in general and in the subfield of political communication in particular has been very limited. This research has shown it has utility however to explain voter behavior and voter turnout in elections (Fishbein, Ajzen, \& Hinkle, 1980; Kunz, 2005).

The specific research question we address here is the extent to which the TPB can account for online campaigning among political candidates in the 2009 state election of North Rhine-Westphalia. In other words, to what extent are individual candidates' intentions to use 
the Web and actual use of it, predicted by their psychological orientation and attitudes toward the technology?

Breaking our research question down into its component parts we identify the three key determinants of behavior specified by the theory - attitude, subjective norm and perceived control and express these as hypotheses. Our first hypothesis is quite simple political candidates who have a positive attitude towards the Internet will plan to use it in their campaign:

H1: The more positive candidates' attitude towards the Internet is then the stronger their intention to use it in their campaign will be.

The subjective norm forms the second indirect determinant of behavior and refers to the social pressure that the candidates perceive. We assume that state politicians primarily compare their campaign activities to those of competing candidates and parties. Our second hypothesis is as follows:

H2: The more favorably candidates perceive their social environment to judge online activities (subjective norm) then the stronger their intention to use it in the campaign will be.

Perceived control is the third determinant of behavioral intentions. People who believe that they are able to control their own behavior are more likely to actually perform this behavior. Hence hypothesis 3 is:

H3: The more candidates perceive they have behavioral control over their online campaign activities then the stronger their intention to use it in the campaign will be.

Most of the studies applying the Theory of Planned Behavior examine how attitudes, norms and perceived control influence behavioral intentions rather than actual behaviors themselves. The study design used here allows for the candidates' actual behavior to be analyzed as well as their intentions. According to the theory we assume that behavioral intention is the strongest predictor of behavior. Moreover, we expect control beliefs to have a more direct impact on behavior than the other types of prior dispositions because the ability to 
perform a behavior is a prerequisite for actually being able to perform it (Ajzen, 1991, pp. 184f.; Ajzen \& Madden, 1986, pp. 458f.). Thus while in general we expect that candidates' actual online activities are strongly positively correlated with their behavioral intentions we hypothesize that:

H4: Perceptions of behavioral control over their online campaign activities will have a direct effect on candidates' actual practice of campaigning online.

We test these four hypotheses for the use of personal Web sites and of social network sites by candidates during the state election campaign in order to be able to examine the validity of the Theory of Planned Behavior for two different cases. We do not presuppose any differences as to how well the theory should work in each of the cases as the theory is supposed to be applicable to various contexts. However, there can be differences in the adequateness of the theory as Fishbein \& Ajzen (2010, p. 180) suggest that the relative importance of attitude, social norms and behavioral control can vary depending on the individual, group or behavioral intention considered. Also, one or more determinants of behavioral intention can be irrelevant. However, it also clear that the explanatory power differs according to the context. The findings of Doll et al. (2000) indicated limited to no influence of subjective norms on behavioral intentions, while others emphasize the significance of social pressure exerted by specific groups (Ho et al., 2008) or the importance of descriptive norms (Park et al., 2010). The impact of perceived control also varies across studies (Doll et al., 2000; Ho et al., 2008; Liu, 2010). We cannot infer from other studies though to what extent this could be the case when comparing personal Web sites and social networks. We believe that the theory can be applied to both types of internet tools and we use Web 1.0 and Web 2.0 solely in order to test the theory for two cases.

\section{Data and Measurement}

\section{Method and sample}


With 18 million inhabitants North Rhine-Westphalia is the biggest of all sixteen German states in terms of population. Its 13.2 million eligible voters represent more than onefifth $(21.4 \%)$ of the national electorate. Accordingly, state elections in North RhineWestphalia are considered as highly indicative of nationwide political trends. After the 2010 elections the state parliament (Landtag) consists of 181 members who are elected in an mixed member proportional election system with 128 constituencies and the remaining seats filled by party lists. Members of the North Rhine-Westphalia Parliament are full-time professional politicians who enjoy working conditions quite similar to those of their counterparts in Berlin.

A pretest of the survey was run during the local elections in North Rhine-Westphalia in 2009 as an online survey (see Appendix A). The feedback received did lead to the refinement of number of measures for the main study. In particular we adjusted the wording of some sensitive questions for example on the budget, to reduce the number of missing values and also adapted the scale of some variables to the context of state elections (e.g. the time spent online during the campaign).

The data for this analysis were collected during the state elections in North RhineWestphalia, Germany, in 2010. The basic population for the study consisted of all constituency candidates from the five largest parties, meaning 640 candidates plus 39 candidates from groups of nominated candidates. Each candidate received mail-out mail-back paper and pencil questionnaire in the two months prior to the election which improved the response rate compared to the pretest considerably. The candidates' contact details were acquired through the parties' main offices in North Rhine-Westphalia. The surveys were sent on March 15, 2010 and a reminder sent on April 9, 2010. A total of 369 questionnaires were returned. Three cases were excluded because of a high number of missing values which constituted a response rate of 54\%. A further 50 candidates were removed. These were candidates from the groups of nominated candidates because these candidates are usually not active campaigners plus those who did not specify their party membership and their 
constituencies. Thus the sample consisted of 316 candidates. Members of the Conservatives (13\%) and the Left Party (18\%) were slightly underrepresented compared with their overall presence in the population which was $20 \%$ respectively. Green party candidates were overrepresented at (26\%) compared with $20 \%$ in the population. Differences in survey participation can be due to different ways of contacting candidates. For example in the case of the Conservative Party, the head office of the party was contacted which then redistributed the questionnaires. In other cases, such as the Green Party, candidates could be contacted directly.

For the Web audit we systematically identified official campaign sites and social media profile sthrough an online audit of sites using the Google search engine. This involved inserting the first and last name of the candidate paired with his party affiliation as a search string. We recorded usage of two types of web presence - personal political Web sites which we refer to as Web 1.0 in the subsequent analysis and Web 2.0 tools. The web 2.0 tools were broken down into three types - Social Networks profiles, YouTube channels and Twitter pages which we label Web 2.0. Profiles or Web sites that were not related to the campaign of the candidate and where only private information was presented were excluded. We did not analyze the contents and features of these channels and measure levels of interactivity but simply their presence or absence.

\section{Measures}

Our first set of measures deals with the key independent variables as set out by the TPB, namely attitudes, subjective norms and perceived behavioral control. For each one we have identified survey items that measure these orientations in relation to the Internet as a technology and online campaigning more specifically. ${ }^{7}$

\footnotetext{
${ }^{7}$ Question wording, response categories and the exact composition of measures can be found in the Appendix A. The full survey can be downloaded at http://www.uni-muenster.de/Kowi/kmg/candidatesurvey2010.html.
} 
A limitation of the measures that we acknowledge from the outset is that the survey was not designed to test the theory of planned behavior and thus items do not fully comply with Ajzen's (2012) suggestions for questionnaire design. This has meant in certain cases we have used structural or observed variables as proxies for perceptions of behavioral control, i.e. internet use and incumbency. Also we have sometimes had to rely on fewer items to capture a latent variable. Despite these limitations we still find that our measures yield a good model fit (results reported below).

We assume that attitudes toward online campaigning could be divided into two basic types - those which were based on its instrumental value and a more general affinity or affect toward the technology. To measure the instrumental value the candidate placed on the technology we used two questions that related to how far they thought that voters can be persuaded through online campaigning. ${ }^{8}$ The items indicate a reliable scale (alpha=.85) and were converted into an additive index which represents the instrumental aspect of the attitude construct. The affective aspect of internet use was one of the variables that we had to use behavioral measures to assess. We used two items - the time a candidate spends on the Internet on a normal working day and during the election campaign. We recognize that this is an indirect and implicit measure of an affective variable and does not capture the candidate's actual emotions or attitudes toward the internet. That said we would expect that positive attitudes to the technology would at least correlate with a more extensive use of online media.

\footnotetext{
${ }^{8}$ The belief in the vote winning capacity of online media should actually be based on the assumption that a considerable number of voters will use the internet for their political information on a regular basis. Surprisingly the correlation of both items with the expected internet use of voters ("What do you think, how many voters use the internet for political information on a daily basis?") is rather low. Cronbach's alpha is reduced to .68 once all three items are subjected to reliability analysis. Hence, we decided to exclude perceptions of voters internet use from the scale. When entered separately in the final models perceived internet use of voters yields no significant effect on the intention of candidates to campaign online.
} 
Both variables were logged to control for outliers. Although alpha was only .475, we converted the items into an additive index. The measure can for obvious reasons be considered as internally consistent as both items capture the same empirical phenomenon, the time spent online. One could argue that direct measures of internet use are not valid for capturing attitude and even affective attitudes.

Subjective norms regarding internet campaigning were divided into two components, a descriptive and injunctive norm. The descriptive norm was specifically seen as indicating the candidate's beliefs about what kind of campaign behavior is justifiable and appropriate in the given situation. The items yield a very high reliability (alpha=.93) and were converted into a single scale. In order to measure the injunctive norm, we use the concept of the "hostile media perception" (Vallone et al., 1985). We suggest that the candidates regard the use of online media as appropriate if they think that the traditional mass media covers them or their party critically or inadequately and therefore try to reach their voters through other channels. We asked for the coverage of the candidates' party because not every candidate expects journalistic coverage of himself or herself. Negative coverage of the party is supposed to be perceived as problematic for the candidates' election campaign and to come across as an incentive to employ other media. ${ }^{9}$ As Cronbach`s alpha was acceptable (alpha=.86) the three original items were averaged to create a new scale capturing the injunctive norm to campaign online.

Finally to measure the perceived behavioral control element of the explanatory model, following Bandura (1991) we use the notion of self-efficacy. This concept is based on the

\footnotetext{
${ }^{9}$ The descriptive norm could also be measured as the internet penetration in a candidate's constituency. This may influence a candidate's online campaigning and can also grasp the voters' potential to exert group pressure. However, we strived for a measure related to the candidates' perceptions. We argue that objective data such as internet penetration is relevant to behavior only in the way it is perceived individually. Therefore, we used the candidates' perceptions as measures.
} 
correlation of two dispositions: the belief in one's ability to act and the belief in the effectiveness of one's behavior. We suggest that the belief in one's ability to run a successful campaign is influenced by previous positive experience. This experience is measured through incumbency capturing the success in the preceding election, the number of election campaigns capturing campaign experience and the length of party membership capturing general political experience. In order to integrate a direct measure of self-efficacy we asked for the presumed chances of winning the mandate. The four items were subjected to Exploratory Factor Analysis (principal component analysis) which resulted in a single factor with an Eigenvalue of 2.3 and explaining $56 \%$ of variance of the four items. Cronbach`s alpha indicate reliability (alpha=.72) for the factor. Thus, the factor scores are used as measurement of perceived behavioral control.

Although measurement issues need to be taken into account we believe that the items used in this study are valid and reliable and we can offer an alternative theoretical explanation as to why for example the measures of perceived behavioral control are related to the use of online campaigning. The status of a candidate is not only a proxy for an increased chance of winning or resources but a variable capturing the candidates' self-confidence in election campaigns and in their potential to collect votes. The more self-confident a candidate is, the more he or she is willing to participate in more unknown and venturous forms of communication such as online media.

For our dependent variables we used both survey data and actual observed behavior. For behavioral intention we asked the candidates in the survey about their plans on using the Internet during the campaign, in particular the planned use of personal Web sites and of social networks. The second dependent variable - candidates' actual behavior was measured independently of the survey through an audit of online media use during the last three days before the election. We used a simple binary scoring system, allocating 1 point if they had a Web site and 0 if not. The same system was applied to the Web 2.0 tools. Since the survey 
had captured the candidate's constituency and party membership it was possible to map the Web audit data to the survey findings.

\section{Research Design and Methodology}

First we will look at descriptive and simple bivariate distributions of the variables capturing the different elements of the Theory of Planned Behavior. Then our hypotheses are tested using structural equation modeling in AMOS 19 (Arbuckle, 2010) with maximumlikelihood estimation. This tool has proven to be especially appropriate for testing theories which incorporate latent constructs, such as the Theory of Planned Behavior (Savalei \& Bentler, 2010). The chi-square statistics is used as an estimate for model fit, with a nonsignificant chi-square value indicating that the model fits the data well (Bollen, 1989). Additional common model parameters are used to assess the model fit (Browne \& Cudeck, 1993; Hair et al., 2006, p. 752; Hu \& Bentler, 1999): The ratio of chi-square value and degrees of freedom (a value below 5 indicates a good model fit), the Root Mean Square Error of Approximation (RMSEA, should be below 0.8) and the Comparative Fit Index (CFI, should be greater than 0.9).

We argue in this paper that individual attitudes and subjective assessments of the Internet are a critical and overlooked factor in models seeking to explain patterns and adoption of online campaigning. Research to date on cyber campaigning has produced a number of findings on structural determinants of online campaigning such as resources, party membership, age or status of the candidates. While our theoretical focus is not on these variables our model does capture their effects indirectly. The element of perceived behavioral control entails a number of variables capturing resources and status of the candidates in the form of incumbency and the candidate's campaign and political experience. In addition we included more explicit measures of candidate resources with controls for the size of the 
campaign budget of each candidate ${ }^{10}$ and the candidate's party affiliation and age (see appendix A for further details of measures).

\section{Results}

\section{Descriptive Analysis}

A first question we sought to address was whether a gap existed between candidates' attitude toward the Internet and their actual behavior. Interestingly the comparison of the frequencies of our two dependent variables reveals a discrepancy with $64 \%$ of the candidates claiming that they are planning to use a personal website whereas the online investigation only found the Web site of $53 \%$ of the candidates. This gap was greater for Web 2.0 technology with the ratio of intended use and actual use for social networks being $57 \%$ to $30 \%$. When the survey was distributed six weeks before the election the majority of the candidates were planning on using some kind of online campaigning tool. Three days before the election the number of candidates actually using the online tools they had planned on implementing had decreased. This demonstrates that there is a need to examine which motivational factors are behind the intention to use the Internet during the campaign to be able to explain why intention does not always result in actual behavior.

Turning to the findings for our key independent variables we can see with respect to the candidates' attitudes towards online campaigning that on average, the candidates of all parties use the Internet about 41 minutes per day for political information and current events. During the election campaign, the candidates estimate that they use the Internet to discuss politics and inform voters about their campaign for about 4 hours daily $(\mathrm{SD}=3.5)$. The candidates estimate that there is an average effect of online campaigning on their supporters $(\mathrm{M}=2.6 ; \mathrm{SD}=1.1)$. The voters of the other parties, however, are perceived as easier to

\footnotetext{
${ }^{10}$ The response rate on the budget item was relatively high - $68 \%$ (216 out of 316$)$ candidates supplied the information on their budget). The range is from $0 €$ to $40.000 €$ ( 0 meaning that a candidate actually indicated that he/she had no budget for the campaign). Mean=8.303€ and SD $=7.827 €$.
} 
influence $(\mathrm{M}=3.0, \mathrm{SD}=1.0)$. This supports the notion of the third person effect (Davison, 1983) for online campaigning.

Regarding the subjective norms, the candidates also think of the influence of the Internet on the campaigning strategy of their party as moderate $(\mathrm{M}=2.7, \mathrm{SD}=1.1)$. The influence on the strategy of other parties is estimated as only slightly stronger $(\mathrm{M}=2.9$, $\mathrm{SD}=1.1)$ and the influence on other candidates $(\mathrm{M}=2.6, \mathrm{SD}=1.0)$ as similar to the influence on their party. In general, the candidates' perceptions that the media coverage is hostile is not very strong $(M=2.6, S D=.8)$ while the press is perceived as least $(M=2.5, S D=1.0)$ and the radio as most hostile $(\mathrm{M}=2.8, \mathrm{SD}=.9)$.

Incumbency serves as a measure for perceived behavioral control. In our sample, only $18.5 \%(n=58)$ were incumbents running for re-election. For the majority of the candidates $(64 \%, n=203)$ this campaign was their first election campaign. Among those candidates who had run before a candidate had experienced between one and two election campaigns $(\mathrm{M}=1.6$, $\mathrm{SD}=1.1)$. The average candidate has been a member of his party for 16 years $(\mathrm{SD}=11.4)$. The variable for the perceived chances of winning was recoded into a binary variable capturing the chances of winning to be rather low $(37 \%, \mathrm{n}=116)$ or rather high $(63 \%, \mathrm{n}=200)$ with most of the candidates being rather optimistic.

\section{Hypotheses Testing}

In the first model (Figure 1), the intention to use a personal Web site and the actual employment of it constitute the dependent variables. The figures show the standardized regression weights of significant paths. The chi-square value of $8.031(\mathrm{df}=4 ; \mathrm{p}=.090)$ not being significant, the ratio chi-square to degrees of freedom $=2.01, \mathrm{RMSEA}=.057$ and $\mathrm{CFI}=.98$ indicate a good model fit. We check the paths for significance to test whether the results can be transferred to the basic population, that is, other candidates and different election campaigns. 
The attitude variables influence the behavioral intention significantly. The individual use of the Internet (affective aspect) predicts behavioral intention slightly better than the instrumental aspect of being able to persuade voters through the Internet. Neither the perception that political candidates and parties adapt to the Internet (descriptive norm) nor candidates being unsatisfied with the coverage of their party in the traditional mass media (injunctive norm) yield significant effects on behavioral intention. However, the descriptive norm is only slightly not significant $(\mathrm{p}=.078, \beta=.10)$ and may have been significant if the sample was larger. Nonetheless, the injunctive norm does not predict behavioral intention at all $(\mathrm{p}=.843, \beta=.01)$. Perceived behavioral control has a positive and highly significant effect and is the strongest predictor of the dependent variables of the model. Coherent with the Theory of Planned Behavior, the effect on behavioral intention is greater than on actual behavior. At the same time, the main effect of perceived behavioral control on behavior $(B=.27)$ is greater than the mediated effect of perceived behavioral control and behavioral intention on behavior $(\beta=.15)$.

Regarding the controls, it turns out that the budget is not significantly correlated with behavioral intention but has a significant effect on Web site usage $(r=.15)$ (not shown in the figure). However, the effects of the perceived behavioral control on both dependent variables remain unaffected, indicating that our measure of the latent construct represents more than just tangible resources.

Overall, the three significant predictors explain $15 \%$ of variance of behavioral intention. Behavioral intention is highly correlated with the actual use of a personal Web site so that in total the model explains $35 \%$ of variance of the actual behavior of the candidates. The effect of behavioral intention on behavior is slightly stronger $(\beta=.445)$ than the total effect (main and indirect effects) of perceived behavioral control $(\beta=.418)$ which is also coherent with the Theory of Planned Behavior. 
The use of a candidate profile on a social network for campaigning purposes constitutes the dependent variable in the second model with which we test the applicability of the Theory of Planned Behavior to online campaigning (Figure 2). Again, the model fit indices reveal a good model fit as the chi-square value is $5.284(\mathrm{df}=4 ; \mathrm{p}=.259)$ and not significant, chi-square/df-ratio is 1.321 , RMSEA=.032 and CFI=.990. However, the explained variance of behavioral intention is substantially lower than in the first model.

\section{[Insert Figure 2 about here]}

This model shows a significant effect of the candidates' individual internet use on behavioral intention $(B=.13 ; \mathrm{p}=.02)$. On the contrary, the perception that online campaigning can persuade voters does not affect the behavioral intention of using a social network account during the campaign. The results for the descriptive norm are similar to the first model. The injunctive norm predicts behavioral intention now significantly although the effect is not that strong $(\beta=.14 ; \mathrm{p}=.013)$. The candidates are more inclined to use social networks if they think that the traditional mass media does not cover her or his party very well. Perceived behavioral control does not yield any effects on either behavioral intention or actual behavior when social networks are concerned. Overall, the predictors only explain $4 \%$ of variance of the behavioral intention to use a social network profile. As expected, behavioral intention is highly correlated with actual behavior so that $27 \%$ of variance of behavior can be explained.

\section{Discussion}

In this paper we have used the Theory of Planned Behavior to explain patterns of Web campaign activity among candidates in a German state level election. The theory is centered on explaining the relationship of attitudes and behavior and argues that various dispositions and perceptions lead to behavioral intentions which are a requisite for actual behavior. We have tested its applicability to account for candidates' use of the Web in their election 
campaigns and thus added an important psychological dimension to accounts of Web campaigning. Our findings revealed support for the use of the theory, although the individual factors components of the theory vary in importance, depending on the type of digital media being considered.

In general the strongest predictor of the use of online media in election campaigns is a positive attitude towards the Internet which is measured as the time spent online. This is true for personal Web sites and social networks for campaign communication. In terms of their instrumental value, however, social networks sites are not seen as holding a strong potential to win votes. We conclude that candidates use the social Web because of its symbolic function. It is less the expectation to win votes which leads candidates to use social media but the hope not to lose voters (young voters in particular) by symbolizing to be modern, open minded and up to date. These results support hypothesis 1 regarding the affective aspects of attitudes and for personal Web sites also for the instrumental aspect of attitudes.

In addition to its symbolic function, the intention to use social networks in constituency campaigns is elicited by other media related cognitions. The injunctive norm yields a significant effect in the second model and the intention is greater if candidates perceive the coverage of other mass media as hostile and negative or if critical journalistic reporting is expected. Surprisingly, the notion of the media being hostile does not affect the use of Web sites. The descriptive norm, measured as the perception that other parties and candidates are expecting the candidates to campaign online is not significant in either model. Hypothesis 2, therefore, is rejected.

With respect to perceived behavioral control, our results are also mixed. In the case of personal Web sites, perceived behavioral control is strongly associated with the dependent variables and explains a great share of variance. Hypothesis 3 and 4 are supported for the Web 1.0 model. On the contrary, perceived behavioral control does not play a role for using a social network. We conclude by inference that by now Web 1.0 applications are used by a 
self-confident political establishment whereas Web 2.0 applications are still rather used by younger and less experienced candidates.

That hostile media perceptions do not influence the intention to use a personal Web site significantly could support the assumption that Web sites are not as much perceived as an alternative to traditional media but as a platform for information and campaign messages aimed at journalists. This interpretation sheds additional light on the candidate's belief in Web sites as being able to win votes. There seems to be a 'two-step flow of campaign message' idea behind it. Candidates hope that traditional mass media would pick up the information from Web sites and the traditional news media like television or the press are perceived as being able to influence the voters. In order to further explain why social networks sites are not perceived as vote winning the variable could be refined by measuring whether the candidates think that they will actually reach new audiences and thus new voters by using online media.

We conducted further analysis in order to explain why the descriptive norm does not explain the intention to campaign online. For this we ran a separate model in which we inserted the three items composing the descriptive norm separately (in the main the models reported here they were inserted as one composite variable). This revealed that there were effects which were hidden in the structural equation model using a latent composite. The intention to use a personal Web site, a facebook profile or a twitter account are actually positively correlated with the perception that the candidates' own party is influenced by the opportunity to campaign online. The perception of other parties or competing candidates does not play a role. The additional analysis indicates, that the peer pressure, which the subjective norm captures, is also relevant for the online campaign in a state election; however, the pressure is only exerted by the candidates' parties and not by competitors. Overall, this analysis supports Sudulich et al.'s (2010) assumption that the me too effect (Selnow, 1968) captures the pressure to use new online campaigning techniques. 


\section{Conclusions}

Overall these results show that the Theory of Planned Behavior is a useful framework to adopt if one is seeking to understand the growth of online campaigns. Media-related perceptions appear to be able to partly explain the online campaigning strategy of candidates. However, it is clear that not all elements of the TPB possess the same explanatory power for all types of Web campaigning (Fishbein \& Ajzen, 2010, p. 180).

Overall we find that that the descriptive norm capturing group pressure is the least powerful explanatory element of the model. This was measured here by the perception that other parties or candidates are employing online campaigning techniques. Part of the reason for this lack of significance may be the lack of variance that characterizes this variable. Candidates generally perceive high levels of the use of online campaigning by others and thus it holds limited explanatory power in relation to the outcome variables.

Another key finding of the study is that the discrepancy between behavior and intention is quite large. One reason why intention does not necessarily result in actual behavior might be the politicians' fear of losing control over their online activities (Russmann, 2011). They may intend to use online media but in the end do not employ it to the extent they had envisaged in order not to lose control over their activities. The link between intention and actual behavior is less strong regarding Web sites than Web 2.0. This lack of impact is somewhat surprising. It may be connected with resources required to run a site. It may also be due to the fact that candidates perceive Web sites as information providing platforms and find that during the course of the campaign they have sufficient coverage from the mass media they might not find it necessary to have a Web site.

In general, the models presented here only explain little variance of behavioral intention, especially in the case of social media. The small share of explained variance may not only be caused by measurement issues but also by our type of modeling. As similar studies have shown, structural equation models using composites of multiple items yields 
rather conservative estimates of path coefficients. Structural equation models with complete latent variables usually reveal significantly higher coefficients because they take the measurement error of each observed variable into account (Stephenson \& Holbert, 2003). These differences are also apparent in our analysis. In a complete model with latent variables, $23 \%$ of variance of the behavioral intention to use a Web site and $37 \%$ of variance of actual behavior are explained.11 At the same time, the chi-square value becomes significant suggesting that the model does not fit the data very well. This happens in about $80 \%$ of models similar to ours published in communication sciences (Holbert \& Stephenson, 2002). As the chi-square value is susceptible to sample size, we expect that this is due to our rather small sample, bashing the otherwise well-fitting structural model. Given a sample size of approx. 300 cases we therefore consider latent composite modeling to be the appropriate strategy, having in mind that significant correlations between variables could be detected with both kinds of modeling.

Self-efficacy, trust in their abilities and belief in a successful campaign are the strongest predictors of the use of Web 1.0 applications. Thus, Web 1.0 is no longer the medium of underdogs and newcomers trying to find an alternative to the mass media and to reach voters directly. Cyber campaigning on Web sites is done by self-confident and promising candidates in Germany, even at the state level. As it may seem counterintuitive that older and more experienced candidates see less constraints on using a Web site than younger candidates, this result could be further interpreted through an investigation of the types of Web sites being used and the way they are used. This also taps the question as to whether there is a clear distinction between Web 1.0 and Web 2.0. It can be misleading to categorize a Web site as Web 1.0 without considering its design, including possible interactive and participatory features. Longer serving candidates are probably more likely to have

\footnotetext{
${ }^{11}$ However, the explained variance in the model predicting the use of social networks improves only slightly.
} 
sophisticated yet highly informative Web sites. If this was the case it would corroborate the interpretation that Web sites are mainly designed with journalists as their target groups.

The results must also be interpreted against the backdrop of the electoral context. The election studied here was being held at state level. Herrnson et al. (2007) point out that in state legislative elections constituency characteristics and voter demographics matter. These are contextual factors and constraints which are not included in the models presented. Future studies should include measures of perceptions of these constituency characteristics in order to specify the more local nature of state elections.

Finally, we can draw conclusions about the correlation between online campaigning and electoral performance. Research has yielded some evidence that online campaigning can improve the electoral performance (e.g. Gibson \& McAllister, 2011). At the same time, only few voters actually use the Internet for political information. Therefore, it is controversial if the correlation between online campaigning and election results can actually be regarded as a causal effect. The results of this paper would suggest reversing the causal direction (D’Angelo, 1998; Sudulich \& Wall, 2010). Promising candidates are self-confident enough to present themselves convincingly on the Internet whereas less confident challengers are more hesitant or rather avoid the Internet. Online campaigning, therefore, while it may help to contribute to electoral success is according to the findings of this analysis more likely to be a consequence of electoral success. 


\section{References}

Ajzen, I. (1985). From intentions to actions: A Theory of Planned Behavior. In J. Kuhl, \& J. Beckmann (Eds.), Action Control: From Cognition to Behavior (pp. 11-39). Heidelberg, Germany: Springer.

Ajzen, I. (1991). The Theory of Planned Behavior. Organizational Behavior and Human Decision Processes, 50(2), 179-211.

Ajzen, I. (2012). Constructing a Theory of Planned Behavior questionnaire. Retrieved March, 20, 2012, from http://people.umass.edu/aizen/tpb.html

Ajzen, I., \& Fishbein, M. (1980). Understanding attitudes and predicting social behavior. Englewood-Cliffs, N.J.: Prentice-Hall.

Ajzen, I., \& Madden, T. J. (1986). Prediction of goal-directed behavior: Attitudes, intentions, and perceived behavioral control. Journal of Experimental Social Psychology, 22, 453474.

Armitage, C.J., \& Connor, M. (2001). Efficacy of the Theory of Planned Behaviour: A metaanalytic review. British Journal of Social Psychology, 40(4), 471-499.

Arbuckle, J.L. (2010). IBM SPSS Amos 19 user's guide. Chicago, IL: SPSS.

Åström, J., \& Karlsson, M. (2011). Blogging in the shadow of parties: Collectivism and individualism in the Swedish 2010 election. Paper presented at the ECPR Joint Sessions, St. Gallen, 12.-17. April 2011.

Bae, H., \& Kang, S. (2008). The influence of viewing an entertainment-education program on cornea donation intention: A test of the Theory of Planned Behavior. Health Communication, 23(1), 87-95.

Bandura, A. (1991) Social cognitive theory of self-regulation. Organizational Behavior and Human Decision Processes, 50(2), 248-287. 
Becker, J. U., Clement, M., \& Schaedel, U. (2010). The impact of network size and financial incentives on adoption and participation in new online communities. Journal of Media Economics, 23(3), 165-179.

Bieber, C. (2011). Der Online-Wahlkampf im Superwahljahr 2009 [Online campaigning in the election year 2009]. In E.J. Schweitzer, \& S. Albrecht (Eds.), Das Internet im Wahlkampf. Analysen zur Bundestagswahl 2009 [The Internet during election campaigns. Analyses of the German national election 2009] (pp. 69-95). Wiesbaden, Germany: VS.

Biermann, K. (2009). Online-Wahlkampf: Graswurzeln im Netz [Online campaigning. Grass roots on the Internet]. Zeit Online. (2009, September 4) Retrieved November, 12, 2011, from http://www.zeit.de/online/2009/04/internet-wahlkampf-gruene.

Bollen, K. A. (1989). Structural equations with latent variables. New York: Wiley.

Bresnahan, M., Lee, S. Y., Smith, S. W., Shearman, S., Nebashi, R., Park, C. Y., \& Yoo, J. (2007). A Theory of Planned Behavior study of college students' intention to register as organ donors in Japan, Korea, and the United States. Health Communication, 21(3), 201-211.

Browne, M. W., \& Cudeck, R. (1993). Alternative ways of assessing model fit. In K. Bollen, \& J. S. Long (Eds.), Testing structural equation models (pp. 136-162). Newsbury Park, CA: Sage.

Chadwick, A, \& Howard, P. N. (2009). Introduction: New directions in internet politics research. In A. Chadwick, \& P. N. Howard (Eds.), Routledge Handbook of Internet Politics (pp. 1-9). London: Routledge.

D'Alessio, D. (1997). Use of the World Wide Web in the 1996 US election. Electoral Studies 16, 489-500. 
Davis, R, Baumgartner, J. C., Francia, P. L., \& Morris, J. S. (2009). The Internet in U.S. election campaigns. In A. Chadwick, \& P. N. Howard (Eds.), Routledge Handbook of Internet Politics (pp. 13-24). London: Routledge.

Davison, W. P. (1983). The third-person effect in communication. Public Opinion Quarterly, $47,1-15$.

derFreitag (2009). No we can't. (2009, September 23) Retrieved November, 13, 2011, from http://www.freitag.de/wochenthema/0939-wahlkampf-spd-wahlkampfzentrale-insider.

Doll, J., Petersen, L., \& Rudolf, M. (2000). Determinanten der Internetnutzung von Gymnasiasten und Studenten - Eine Anwendung der Theorie geplanten und rollengesteuerten Verhaltens [Determinants of internet use of pupils and students - an application of the theory of planned behavior]. Medienpsychologie, 12(1), 5-22.

Druckman, J., Kifer, M. J., \& Parkin, M. (forthcoming). U.S. Congressional campaign communications in an internet age, Journal of Elections, Public Opinion \& Parties. Available from http://faculty.wcas.northwestern.edu/ jnd260/pub/Druckman\%20Kifer\%20Parkin\%20J EPOP\%202013.pdf

Fishbein, M., \& Ajzen, I. (2010). Predicting and changing behavior. The reasoned action approach. New York: Psychology Press.

Fishbein, M., Ajzen, I., \& Hinkle, R. (1980). Predicting and understanding voting in American elections: Effects of external variables. In I. Ajzen, \& M. Fishbein (Eds.), Understanding attitudes and predicting social behaviour (pp. 173-195). EnglewoodCliffs, N.J.: Prentice-Hall.

George, J. F. (2002). Influences on the Internet to make internet purchases. Internet Research, 12(2), 165-180. 
Gibson, R. K., \& Ward, S. (1998). UK political parties and the Internet—-Politics as usual” in the new media? Harvard International Journal of Press/Politics, 3(3), 14-38.

Gibson, R. K., Margolis, M., Resnick, D., \& Ward, S. (2003). Election campaigning on the WWW in the US and UK: A comparative analysis. Party Politics, 9(1), 47-76.

Gibson, R. K., \& McAllister, I. (2011). Do online election campaigns win votes? The 2007 Australian YouTube election. Political Communication, 28, 227-244.

Golan, G. J., \& Banning, S. A. (2008) Exploring a link between the Third-Person-Effect and the Theory of Reasoned Action. Beneficial ads and social expectations. American Behavioral Scientist, 52(2), 208-224.

Gulati, G. J., \& Williams, C. B. (2007). Closing the gap, raising the bar. Candidate Web site communication in the 2006 campaigns for Congress. Social Science Computer Review, $25,443-465$

Hair, J. F. J., Black, W. C., Babin, B. J., Anderson, R. E., \& Tatham, R. L. (2006). Multivariate data analysis (6th ed.). Upper Saddle River, New Jersey: Pearson, Prentice Hall.

Hippler, M. (2010). NRW-Wahl: Müder Wahlkampf im Netz [North Rhine-Westphalian election campaign: Slow online campaigning]. Zeit Online. (2010, May 7) Retrieved November, 13, 2011, http://www.zeit.de/digital/internet/2010-05/online-wahlkampf-nrw

Ho, S. S., Lee, W., \& Hameed, S. S. (2008). Muslim surfers on the internet: Using the theory of planned behaviour to examine the factors influencing engagement in online religious activities. new media \& society, 10(1), 93-113.

Holbert, R. L., \& Stephenson, M. T. (2002). Structural equation modeling in the communication sciences, 1995-2000. Human Communication Research, 28, 531-551. 
Hu, L., \& Bentler, P. M. (1999). Cut-off criteria for fit indexes in covariance structure analysis: conventional criteria versus new alternatives. Structural Equation Modeling, $6(1), 1-55$.

Kaid, L. L. (2006). Political Web wars: The use of the Internet for political advertising. In A. P. Williams, \& J. C. Tedesco (Eds.), The internet election: Perspectives on the Web in campaign 2004 (pp. 67-82). Lanham, MD: Rowman \& Littlefield.

Kunz, V. (2005). Persönlichkeitseigenschaften und Wahlverhalten in den alten und neuen Bundesländern nach der Theorie des überlegten Handelns [Personality characteristics and voting behavior in the old and new German state with respect to the theory of planned behavior]. In S. Schumann (Ed.), Persönlichkeit: Eine vergessene Größe der empirischen Sozialforschung [Personality. A forgotten variable in empirical social reserach] (pp. 117-136). Wiesbaden, Germany: VS Verlag.

Kunze, B., Bauer, Y., \& Becker, F. (2011). Der Online-Wahlkampf im Praxis-Test: Die WebAktivitäten von Direktkandidaten zur Bundestagswahl 2009 [Online campaigning in practice. Candidates ' web activities in the national election 2009]. In E. J. Schweitzer, \& S. Albrecht (Eds.), Das Internet im Wahlkampf. Analysen zur Bundestagswahl 2009 [The Internet during election campaigns. Analyses of the German national election 2009] (pp. 244-263). Wiesbaden, Germany: VS.

LaPiere, R.T. (1934). Attitudes vs. actions. Social Forces, 13(1/4), 230-237.

Lev-On, A. (2011). Campaigning online: Use of the Internet by parties, candidates and voters in national and local election campaigns in Israel. Policy \& Internet, 3(1), 1-28.

Lilleker, D. G., \& Jackson, N. A. (2011). Elections 2.0: Comparing e-campaigns in France, Germany, Great Britain and the United States. In E. J. Schweitzer, \& S. Albrecht (Eds.), Das Internet im Wahlkampf. Analysen zur Bundestagswahl 2009 [The Internet during 
election campaigns. Analyses of the German national election 2009] (pp. 96-116). Wiesbaden, Germany: VS.

Lim, H., \& Dubinsky, A. J. (2005). The theory of planned behavior in e-commerce: Making a case for interdependencies between salient beliefs. Psychology \& Marketing, 22(10), 833-855.

Liu, X. (2010) Empirical testing of a theoretical extension of the technology acceptance model: An exploratory study of educational Wikis. Communication Education, 59(1), $52-69$.

Madden, T. J., Scholder-Ellen, P., \& Ajzen, I. (1992). A comparison of the Theory of Planned Behavior and the Theory of Reasoned Action. Personality and Social Psychology Bulletin, 18(1), 3-9.

Maier, M., Tenscher, J., \& Schüller, K (2010). Political marketing in Germany. In J. LeesMarshment, J. Strömbäck, \& C. Rudd (Eds.), Global political marketing (pp. 34-51). New York: Routledge.

Norris, P., \& Curtice, J. (2008). Getting the message out: A two-step model of the role of the Internet in campaign communication flows during the 2005 British General Election. Journal of Information Technology and Politics, 4(4): 3-13.

Papies, D., \& Clement, M. (2007). Die Theorie des geplanten Verhaltens zur Ermittlung von Konsumentenpräferenzen bei Medieninnovationen [The theory of planned behavior for investigating consumers' preferences of media innovations]. Medienwirtschaft, 4, 80-92.

Park, H. S., \& Smith, S. W. (2007). Distinctiveness and influence of subjective norms, personal descriptive and injunctive norms, and societal descriptive and injunctive norms on behavioral intent: A case of two behaviors critical to organ donation. Human Communication Research, 33 (2), 194-218. 
Park, N., Lee, K., \& Jung, Y. (2010). Determinants of uploading user generated video content on the Internet: Toward an integrated model. Paper presented at the conference of the International Communication Association (ICA), Singapore, 22. - 26. June 2010.

Prior, M. (2006). The incumbent in the living room: The rise of television and the incumbency advantage in US House elections. Journal of Politics, 68, 657-673.

Rossmann, C. (2010). Theory of Reasoned Action - Theory of Planned Behavior. BadenBaden, Germany: Nomos.

Russmann, U. (2011). Targeting voters via the Web - A comparative structural analysis of Austrian and German party Web sites. Policy \& Internet, 3(3), 1-23.

Savalei, V., \& Bentler, P. M. (2010). Structural equation modeling. Corsini Encyclopedia of Psychology, 1-3.

Schmitt-Beck, R., \& Mackenrodt, C. (2009). Politikvermittlung durch Massenmedien bei der Bundestagswahl 2005: Nutzungsintensität und Einflüsse auf Einstellungen und Wahlverhalten [Communicating politics via mass media during the national elections 2005. Intensity of use and influence on attitudes and voting behavior]. In F. Marcinkowski, \& B. Pfetsch (Eds.), Politik in der Mediendemokratie [Politics in a media democracy] (pp. 415-446). Wiesbaden, Germany: VS Verlag.

Schneider, F. (2009). Online-Auftritte der Parteien: Im Netz tobt schon der Bundestagswahlkampf [Online presence of parties: The election campaign online has begun]. Welt Online. (2009, February 26) Retrieved November, 12, 2011, from http://www.welt.de/politik/article3278995/Im-Netz-tobt-schon-der-

Bundestagswahlkampf.html.

Schweitzer, E. J. (2006). Professionalisierung im Online-Wahlkampf? Ein Längsschnittvergleich deutscher Partei-Websites zu den Bundestagswahlen 2002 und 
2005 [Professionalization in online campaigns? A longitudinal comparison of German party Web sites during the German national elections 2002 and 2005]. In C. HoltzBacha (Eds.), Die Massenmedien im Wahlkampf. Die Bundestagswahl 2005 [The mass media during election campaigns. The national elections 2005] (183-212). Wiesbaden, Germany: VS.

Schweitzer, E. J. (2010). Politische Websites als Gegenstand der Online-Inhaltsanalyse [Political Web sites as an object of online content analysis]. In M. Welker, \& C. Wünsch (Eds.), Die Online-Inhaltsanalyse. Forschungsobjekt Internet [Online content analysis: The Internet as object under investigation] (pp. 44-102). Cologne, Germany: Herbert von Halem.

Schweitzer, E. J., \& Albrecht, S. (2011). Das Internet im Wahlkampf: Eine Einführung [The Internet during election campaigns. An introduction]. In E. J. Schweitzer, \& S. Albrecht (Eds.), Das Internet im Wahlkampf. Analysen zur Bundestagswahl 2009 [The Internet during election campaigns. Analyses of the German national election 2009] (pp. 9-65). Wiesbaden, Germany: VS.

Selnow, G. W. (1998). Electronic whistle-stops: The impact of the Internet on American politics. Westport, CT: Praeger Publishers.

Stephenson, M. T., \& Holbert L. (2003). A Monte Carlo simulation of observable versus latent variable structural equation modeling techniques. Communication Research, $30(3), 332-354$.

Sudulich, M. L., \& Wall, M. (2010). "Every Little Helps": Cyber-campaigning in the 2007 Irish general election. Journal of Information Technology \& Politics, 7(4), 340-355. 
Sudulich, M. L., Wall, M., Jansen, E., \& Cunningham, K. (2010). Me too for web 2.0? Patterns of online campaigning among candidates in the 2010 UK general elections. Paper presented to EPOP 2010.

Vallone, R. P, Ross, L., \& Lepper, M. R. (1985). The hostile media phenomenon: Biased perceptions and perceptions of media bias in coverage of the Beirut massacre. Journal of Personality and Social Psychology, 49, 577-585.

Weißmüller, L. (2009). CDU: Wahlkampf im Internet. Obama hilf! (2009, February 27) Retrieved November, 13, 2011, from http://www.sueddeutsche.de/politik/cduwahlkampf-im-internet-obama-hilf-1.474467

Wicker, A. W. (1969). Attitudes versus actions: The relationship of verbal and overt behavioral responses to attitude objects. Journal of Social Issues, 25(4), 41-78.

Wiegold, T. (2009). SPD online: Herzstück in Himmelblau. (2009, January 1) Retrieved November, 12, 2011, from http://www.focus.de/politik/deutschland/spd-onlineherzstueck-in-himmelblau_aid_360279.html.

Wolling, J., Schmolinsky, A., \& Emmer, M. (2010). Politiker vernetzt: Wie und warum sich Landtagsabgeordnete online präsentieren [Networked politicians: How and why do members of the state parliament present themselves online?]. In J. Wolling, M. Seifert, \& M. Emmer (Eds.), Politik 2.0? Die Wirkung computervermittelter Kommunikation auf den politischen Prozess [Politics 2.0? The influence of computer-mediated communication on political processes] (pp. 59-83). Baden-Baden, Germany: Nomos.

Zhao, X., \& Cai, X (2008). From self-enhancement to supporting censorship: The ThirdPerson effect process in the case of internet pornography. Mass Communication and Society, 11(4), 437-462. 
Zittel, T. (2009a). Entmedialisierung durch Neue Digitale Medien? Direkte Wählerkommunikation im WWW aus der Sicht von Abgeordneten des Deutschen Bundestages [De-mediatization through new digital media? Direct voter communication online through the perspective of member of the German parliament]. In F. Marcinkowski, \& B. Pfetsch (Eds.), Politik in der Mediendemokratie [Politics in a media democracy] (pp. 366-389). Wiesbaden, Germany: VS Verlag.

Zittel, T. (2009b). Lost in technology? Political parties and the online campaigns of constituency candidates in Germany's mixed member electoral system. Journal of Information Technology \& Politics, 6(3/4), 298-311. 


\section{Appendix A}

Question Wording and Measures

Instrumental aspect of attitude:

What do you think, to what extent does the Internet influence your own voters?

What do you think, to what extent does the Internet influence other voters? (response categories from $1=$ not at all to $5=$ very much)

Affective aspect of attitude:

On a normal working day, how much time do you spend online on political information? During the election campaign, how many hours per week are you spending on political discussions and information online?

\section{Descriptive norm:}

What do you think, to what extent does the Internet influence the election campaign of your party/ the other parties/ the other candidates? (response categories from $1=$ not at all to $5=$ very much)

\section{Injunctive norm:}

What do you think of the press/ television/ radio coverage of the election? Is the coverage of your party very negative, rather negative, neutral, rather positive, very positive?

\section{Perceived behavioral control:}

Incumbency: Were you a member of the state parliament in the previous legislative period?

Campaign experience: Is this your first candidacy or did you run for state parliament already in an earlier election? If so, how often have you run before?

Political experience: For how many years have you been a member of your party?

Presumed chances of winning: If you think about the election campaign and the election, what do you think about the chances of winning in your electoral district? (response categories from 1=I think I cannot win to 5=I think cannot lose)

\section{Behavioral intention:}


To what extent are you planning to use the Internet during the election campaign, irrespective of your party?

Dependent variables:

Survey data: Planned use of the Internet

Which of the following tools are you planning on using in your campaign?

The answers "I will use a personal Web site which is administered by myself or advisors" and "I will use social networks like facebook during the campaign" were coded as binary variables $(1=$ yes, $0=$ no $)$.

Actual observed behavior

Web audit: We used a simple binary scoring system, allocating 1 point if they had a Web site and 0 if not. The same system was applied to the Web 2.0 tools.

Control variables:

Budget:

What was the size of your campaign budget (including party resources, donations, and private funds)? (Measured in raw number of Euro)

Party affiliation:

Which party do you belong to? Conservatives, Social Democrats, Liberals, Green Party or Left Party

Age:

In what year were you born?

\section{Pretest}

- Online survey of political candidates during eight weeks preceding the local elections in North Rhine-Westphalia in 2009

- Run in the three biggest cities in North Rhine-Westphalia (Cologne, Dusseldorf, Dortmund)

- 383 candidates, 99 respondents (response rate: 26 percent) 
Author Note

Frank Marcinkowski

Department of Communications, University of Muenster

Frank Marcinkowski holds a chair in communications at the University of Muenster, Germany. He has published widely in the fields of political communication, media theory, and science communication.

Julia Metag

IPMZ - Institute of Mass Communication and Media Research, University of Zurich

Julia Metag is a Senior Research and Teaching Associate at the University of Zurich, Switzerland. Her research focuses on political communication, science communication, and media effects.

The authors wish to thank Prof. Dr. Rachel Gibson and the anonymous referees for their comments.

Address correspondence to: Prof. Dr. Frank Marcinkowski, Department of Communication, University of Muenster, Bispinghof 9-14, 48143 Muenster, Germany (Email: frank.marcinkowski@uni-muenster.de) 
Figure Captions

Figure 1. Model explaining the use of a personal website during the election campaign.

Figure 2. Model explaining the use of a social network profile during the election campaign. 
Figures

Figure 1

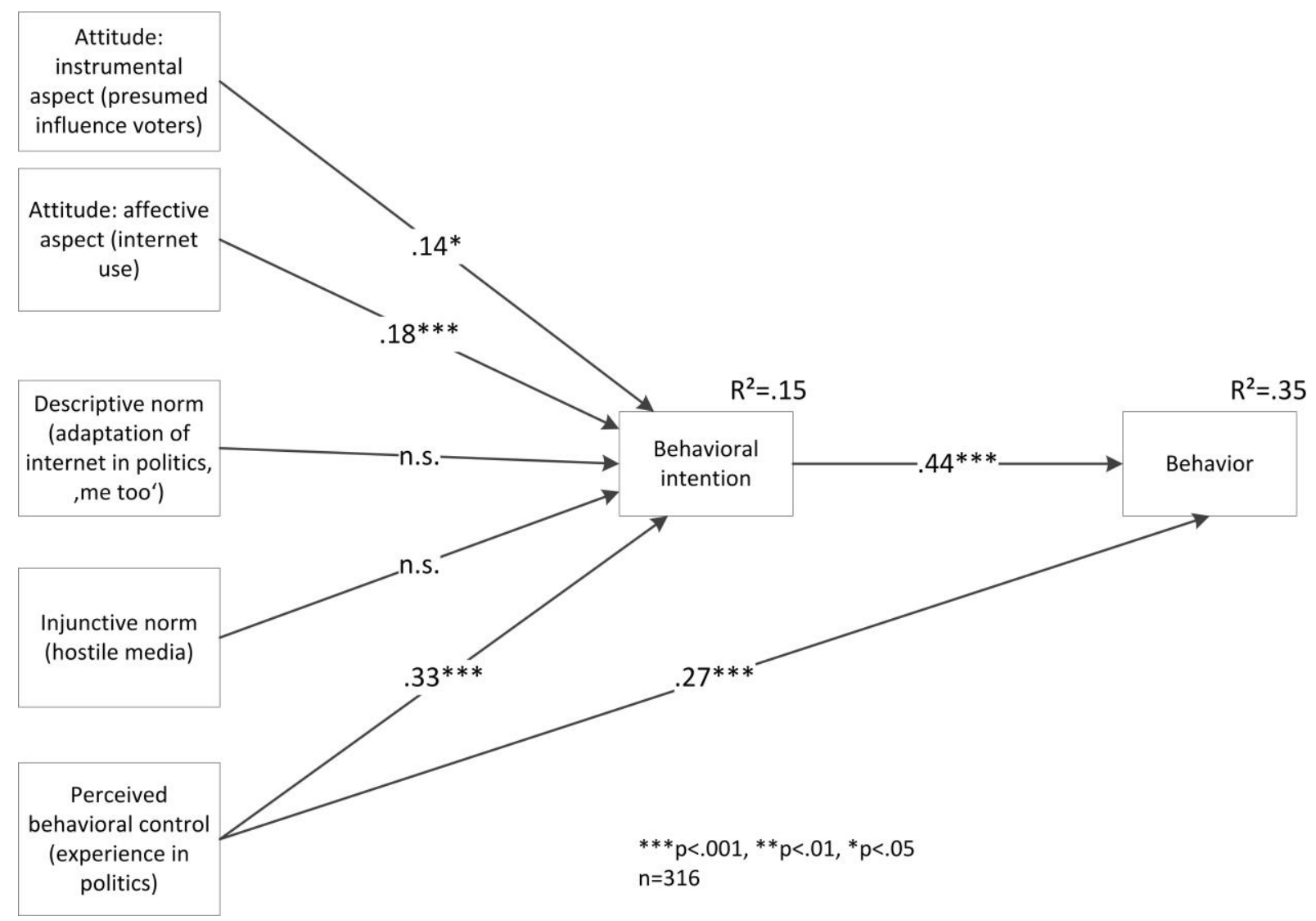


Figure 2

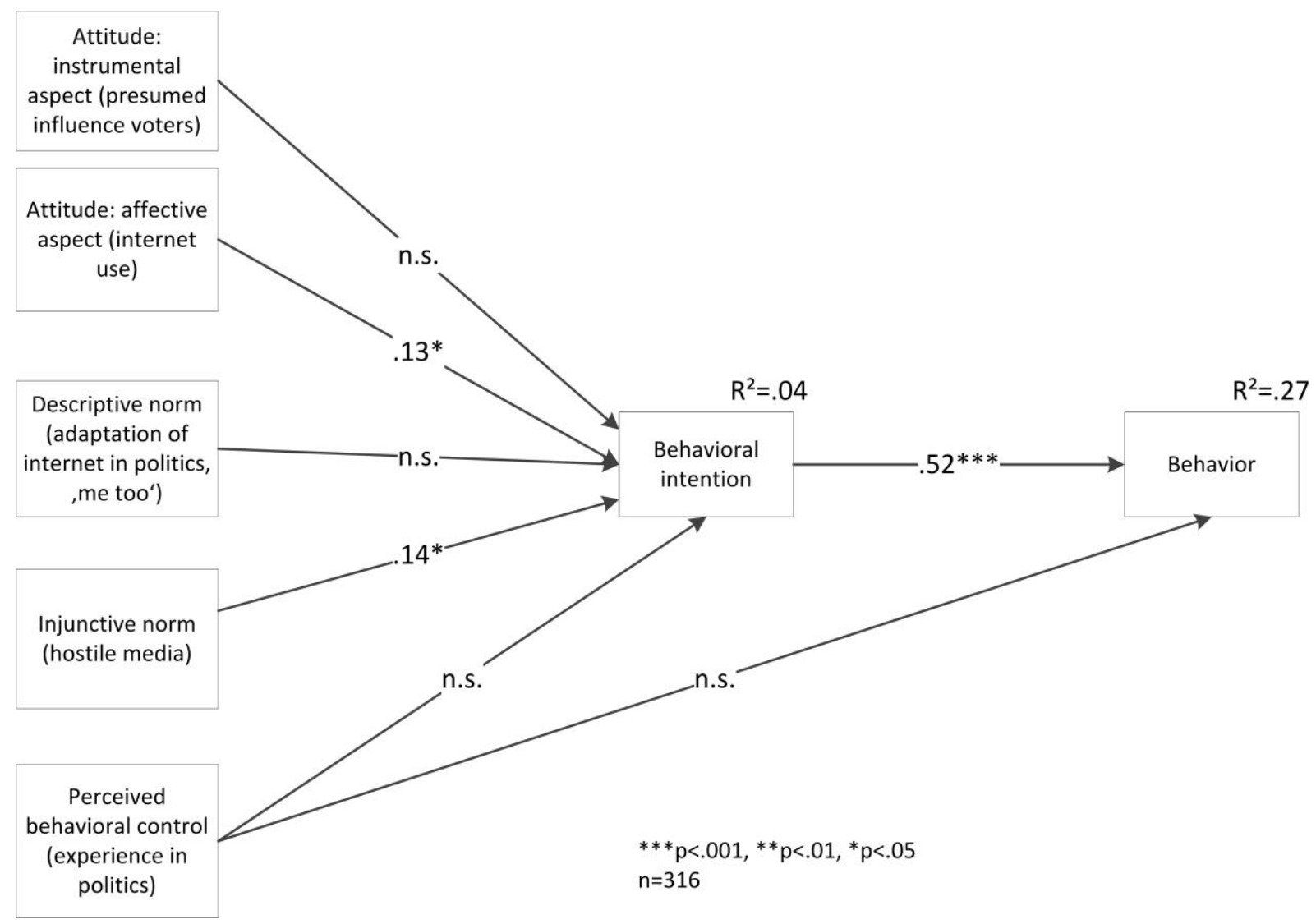

